Volume: 12 Issue: 1 Year: 2015

\title{
Representation of the cartoon controversy on the U.S. newspapers
}

\author{
Yusuf Yüksel ${ }^{1}$ \\ Ayhan Akbulut ${ }^{2}$
}

\begin{abstract}
Cartoon Crisis composed one of the most comprehensive international security problems of the last decade. A Danish newspaper, Jyllands-Posten, published 12 cartoons to satirize Prophet Mohammed in September 2005 which resulted in boycotts, anger and violent protest and thus a global conflict. The dispute over the cartoons has brought out the questions about the relations between the Islamic World and the West, the role of media on those relations, the limits of freedom of speech and right to protests and violence. This study aimed to find out how the cartoon controversy was represented in the US news media and the difference between newspapers depending on the rate of Muslim population in their circulation area. A content analysis of Detroit Free Press, Herald News, Omaha World-News and Wyoming Tribune-Eagle newspapers are used to test the hypothesis about the publication of the cartoons and reaction of the Muslims to this issue. The findings suggest that the newspapers published in Muslim diverse communities are likely to draw more attention to the controversy. However, the difference is not significant. All of the four newspapers present negative views not only about the publication of the cartoons but also the reaction of the Muslims.
\end{abstract}

Keywords: Cartoon Controversy; International Conflicts; Freedom of Speech; Right to Protest; Media.

\section{Introduction}

One of the most extensive international conflicts of the last decade was the conflict started with the publication of Prophet Mohammed's cartoons in a Danish newspaper, internationally known as Cartoon Crisis. The crisis began on $30^{\text {th }}$ of September, 2005. Jyllands-Posten, a Danish newspaper, published 12 cartoons to satirize Prophet Mohammed. At the beginning, the reaction was mostly peaceful and local. However, the editors of Jyllands-Posten, Muslim leaders in Denmark, and Danish politicians have ignored opportunities to keep the controversy at this early stage which have

\footnotetext{
${ }^{1}$ Ph.D., Police Chief in Giresun, Dereli Police Department, yusufyuksel1976@gmail.com

2 Ph.D., Police Chief in TNP HQ, ayh akbulut@yahoo.com
} 
Yüksel, Y., \& Akbulut, A. (2015). Representation of the cartoon controversy on the U.S. newspapers. International Journal of Human Sciences, 12(1), 487-510. doi: 10.14687/ijhs.v12i1.3074

resulted in a global conflict (Fattah, 2006). The cartoons have resulted in boycotts, increasing hatred, and sometimes violent protests across the Islamic world, and eventually triggered the burning of Danish embassies and flags across the Middle East, Nigeria, Pakistan, Afghanistan in February (Reynolds, 2006). In the following days, some governments in Muslim countries, international organizations and some leaders such as Kofi Annan, Bill Clinton and Jack Straw criticized the publication of the cartoons and tried to calm the rage at the same time, worried about the increasing level of violence and casualties. The crisis has been stopped in late February; however permanent tracks in people's mind in the West and Islamic world remained.

The questions emerging after the crisis are mainly the possibility of clash of civilizations, the limits of freedom of speech and the role of media among all these. Following are the right and the way of protest on certain issues, the role of religion in society, religious tolerance, the relationship of Muslim minorities with their broader societies in the West, and the relations between the Islamic World and the West. Due to the role of the media from the beginning of the crisis, this study puts emphasize on the representation of the cartoon controversy on the US newspapers. The Danish newspaper initiated the crisis and then it has spread across the world via TV, the Internet, and newspapers. Some newspapers in France, Germany, and Spain republished some of the cartoons in order to defense freedom of press. In some countries, like Syria and Iran, "beavy press coverage in official news media fostered the demonstrations which ended with Danish embassies in flames" (Reynolds, 2006: 12).

In contrast to European and Middle East counterparts, the news media in the US has followed mostly a different direction. The Rocky Mountain News, The Philadelphia Inquirer and some other small newspapers republished the cartoons, whereas most of the major and well known American newspapers including The New York Times, The Los Angeles Times, The Washington Post and The Chicago tribune did not. Editors of the Philadelphia Inquirer stated that "it was important for readers to understand both sides of the story" (Reynolds, 2006). Representatives of the some newspapers including the New York Times did not publish the cartoons by claiming "the story could be told effectively without publishing images that many would find offensive" (The New York Times, February 4, 2006). Similarly, the politicians in the US have declared more balanced views on the issue. "The Bush Administration initially declared the caricatures offensive while disapproving the violence" (The New York Times, February 4, 2006). US State Department has declared that "Muslims were justified in being offended, while former president Bill Clinton called the cartoons appalling" (USA Today, February 8, 2006). Based on the above mentioned background, main interest of this study is the response of the US news media to 
Yüksel, Y., \& Akbulut, A. (2015). Representation of the cartoon controversy on the U.S. newspapers. International Journal of Human Sciences, 12(1), 487-510. doi: 10.14687/ijhs.v12i1.3074

the cartoon controversy in their content. More specifically, the aim of this study is to find out how the cartoon controversy was represented in the US news media and the difference between them depending on their target population.

Within this context, the hypotheses are offered as follows:

Hypothesis 1: The newspapers in Non-Muslim communities ${ }^{*}$ are more likely to support the publication of the cartoons than the ones in Muslim communities*.

Hypothesis 2: The newspapers in Non-Muslim communities are more likely to oppose the reaction of the Muslims to the cartoons than the ones in Muslim communities.

A content analysis of Detroit Free Press, Herald News, Omaba World-News and Wyoming Tribune-Eagle newspapers are used to test the hypothesis and provide the data for the following research questions. The main research questions of this study are:

1. What is the frequency of the news coverage about the cartoon controversy?

2. What proportion of the stories* regarding to the publication of the cartoons on the newspapers can be categorized as supportive, opposed or neutral/both?

3. What proportion of the stories regarding to the reaction of the Muslims to the cartoons can be categorized as supportive, opposed or neutral/both?

4. Are there any differences in the content of the newspapers depending on Muslim population in their circulation area?

Based on this ground, this article first discusses the concept of freedom of speech and press and provides information about Muslims profile in the US. The literature review is followed by the methodology, findings and discussion.

\section{Freedom of Speech and Press}

Freedom of speech is the right of individuals to express their opinions on any subject freely through communication. It is counted as one of the fundamental human rights by the United

\footnotetext{
* Non-Muslim communities refer to places where Muslim population is not significant in percentage (less than $1 \%$ )

* Muslim communities refer to places where Muslim population is significant in percentage (more than $1 \%$ )

${ }^{*}$ Story concept is used to cover reports, articles, and letters to editor
} 
Yüksel, Y., \& Akbulut, A. (2015). Representation of the cartoon controversy on the U.S. newspapers. International Journal of Human Sciences, 12(1), 487-510. doi: 10.14687/ijhs.v12i1.3074

Nations Universal Declaration of Human Rights of 1948 (UN, 1948). Although the term has gained popularity especially in the last century, the scope of that is still controversial. Most of the people of the world clearly state their support for freedom of speech in principle; however, their reactions to specific examples may change case by case especially to unfavorable statements about the values they believe in, their identity and the groups that they belong to. In some cases freedom of speech may also be accepted as a threat to national security. A range of perspective is stated on the balance between freedom of speech and protection of national security and social peace. Thus, it is worth asking what freedom of speech is and whether it is an absolute right or not. If not, what can be the possible restrictive legal measures?

The supporters of freedom of speech are mostly leans on the arguments of John Stuart Mill. "Mill understands freedom of speech broadly to involve the following: freedom of thought, feeling, conscience, opinion, sentiments, press, association, and the freedom to publish and express opinions" (Ikuenobe, 2003: 400). He emphasizes that the community must allow all ideas, because we can not be sure whether an idea is really false or not. "Individuals and society benefit from a serious exchange of views, even when the other side is wrong" (Martinson, 2005: 119). Mill's model emphasizes the importance of free debate and discussion to improve one's ideas. One of his chief arguments in support of free speech is that "collecting others' responses to one's speech enables one to develop clearer, stronger ideas" (Ikuenobe, 2003, p. 400). He also emphasizes the importance of critical thinking derive from free speech (Ladenson, 1997). Some other scholars oppose to the limitations on freedom of speech and press asserting the idea that "legislation on these issues would result in excluding marginalized groups from the marketplace of ideas" (Brems, 2002: 485)

In the same line of thought, free speech theories in the US are mostly discussed under the theory of 'marketplace of ideas'. This theory suggests that "government should not restrict access to that marketplace, because the value of ideas will appear in the confrontation with other ideas, not in the confrontation with the law: Speech is best met with counter-speech" (Brems, 2002: 485). Americans are guaranteed that right by the First Amendment to the Constitution of the United States (Cowan \& Khatchadourian, 2003).

However, as mentioned shortly, there is still controversy about the limitations of this right in every part of the world depending on political, cultural and social structure of the countries. Most of the countries have some legal restrictions, in addition to the social norms. The people who support restrictions on freedom of speech put emphasize on the harms of racist and hate speech, and fighting words on individuals and on society as a whole (Brems, 2002). Some others support the restrictions for the protection of national security, public order and peace. Mill also draws the limits 
Yüksel, Y., \& Akbulut, A. (2015). Representation of the cartoon controversy on the U.S. newspapers. International Journal of Human Sciences, 12(1), 487-510. doi: 10.14687/ijhs.v12i1.3074

of the freedom through his well-known Harm Principle. The principle simply states that 'the only purpose for which power can be rightfully exercised over any member of a civilized community, against his will, is to prevent harm to others' (Mill, 1978: 9). The limit put by the principle may be applied to any type of freedom and draws the line in between clashing rights and values.

In the US, "freedom of speech has been prioritized among the three highest values by the American public" (Cowan \& Khatchadourian, 2003: 302). This right appears to be more important than the harm of hate speech among Americans. However, there is still a tension between the balance of freedom of speech and the harm of hate and racist speech (Cowan \& Khatchadourian, 2003). Because of the difference in the political background, the restrictions on freedom of speech and press are more limited in the US compared to Europe. These restrictions are based on the following Supreme Court decisions.

"The First Amendment does not unqualifiedly protect all expression. The Supreme Court does balance the individual right with important public interests. Yet case per case balancing is reserved for content-neutral restrictions of speech, regulating time, place and manner of expression. Anti-racist restrictions are related to the content of speech and are therefore accepted only with much more difficultly. The Supreme Court identified a few narrowly defined categories of speech enjoying lower protection. These include libel, obscenity, and fighting words. Underlying the identification of these categories is a balancing between the individual right and the general interest for the entire category. In order to be acceptable, a restriction has to fall within one of these categories" (Brems, 2002: 484).

\section{Muslim Profile in the US}

Significant number of Muslims came to the US in a series of distinguishable periods. Although the early Muslim immigration to the US trace back to $18^{\text {th }}$ century, most of the immigration have taken place in the latter part of the $19^{\text {th }}$ century. Today, Muslims living in the US represent a variety of origins and identities. Each period of immigration has resulted in more diversity in the population of the Muslims in the US (Smith, 2006).

However, it is very difficult to give the exact number of Muslims currently living in the US. Various organizations and scholars have given a wide range of estimates about how many Muslims live in the US. The estimated figures range from two million to nine million. There are some reasons for varying estimates. First and foremost, the US Census Bureau does not collect data on religious identification because of the limitation in the US Constitution (Huda, 2006). Similarly, US 
Yüksel, Y., \& Akbulut, A. (2015). Representation of the cartoon controversy on the U.S. newspapers. International Journal of Human Sciences, 12(1), 487-510. doi: 10.14687/ijhs.v12i1.3074

Immigration Service does not collect information on religious identification of immigrants. Moreover, many mosques and Islamic Centers in the US do not have "formal membership policies, and they seldom keep accurate attendance figures" (Smith, 2006). As a result, there is not an official figure of the Muslim population in the US and there is not a number that is commonly accepted and used by all who have studied Muslim demographics (Smith, 2006).

Due to the ideological and political reasons, Muslim scholars and institutions tend to put the number higher than non-Muslim scholars and institutions. The American Religious Identification Survey (ARIS) estimates "a national population of Muslims up to 2 million" (Kosmin \& Mayer, 2001). According to United States Institute of Peace Special Report, "there are approximately 6 to 7.5 million Muslims in the US" (Huda, 2006). The World Almanac 2001 stated that there are about 5.8 million Muslims in the US (Mujahid, 2001).

There is more consistency between scholars on the places where Muslims live in the US. Today, there are few places in the US where one does not find Muslims living. Despite the growing diversity nationally, Muslims tend to live in the major metropolitan areas. Chicago, New York City, Detroit, Los Angeles, Jersey and San Francisco have more Muslims in residence than any other places (Badry, 2001). According to Mujahid (2001), "20\% of all Muslims live in California, $16 \%$ in New York State, $8 \%$ in Illinois, $4 \%$ in New Jersey and Indiana each, and about $3 \%$ in Michigan, Virginia, and Texas, and Obio each". The figures of ARIS verify the distribution given by Mujahid. Muslims mainly divided in to three ethnic categories. The American Muslim Council reports that " $42 \%$ of all Muslims are African-Americans, $24 \%$ are of South Asian origin and $12 \%$ of Arab origin" (Numan, 1990). Many of these cities mostly reside in a specific ethnic diversity. For example, most of the Iranians reside in Los Angeles and Southeast California and most of the Arabs reside in Detroit and New York (Numan, 1990; Badry, 2001).

The southeast and northwest parts of the US have the fewest Muslim immigrants, with the exceptions of Florida and Seattle (Kosmin \& Mayer, 2001; Mujahid, 2001). Within the Harvard Pluralism Project, a map is produced which shows the distribution of Mosques in the US. This map also suggests more or less the distribution of Muslim population in the US. The figures on this map also verify above mentioned information about the major places where Muslims live. The selection of the location of newspapers in Muslim (New Jersey and Michigan) and Non-Muslim communities (Wyoming and Nebraska) is based on this information which will be further explained in the methodology section. 
Yüksel, Y., \& Akbulut, A. (2015). Representation of the cartoon controversy on the U.S. newspapers. International Journal of Human Sciences, 12(1), 487-510. doi: 10.14687/ijhs.v12i1.3074

Figure 1: Distribution of the Muslim Centers in the U.S.

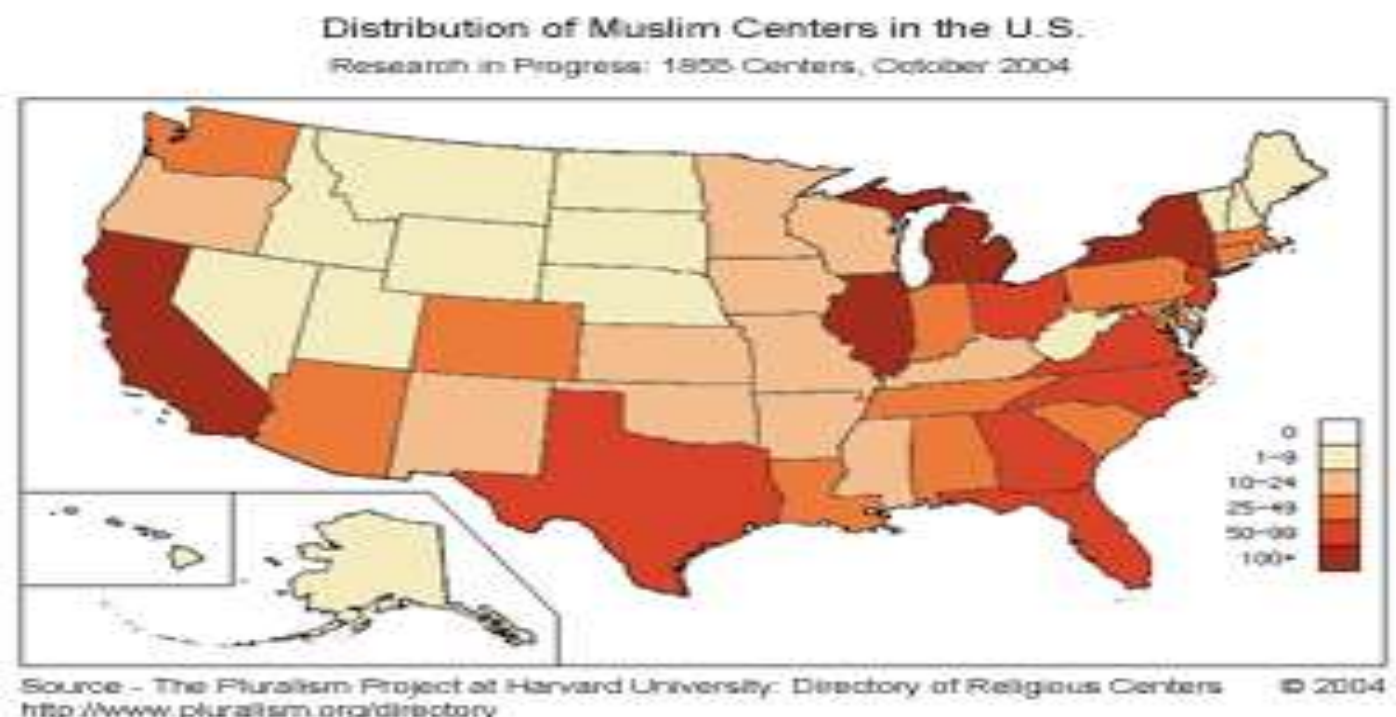

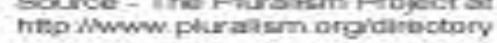

\section{Muslim Population in New Jersey and Michigan}

Media outlets in New Jersey and Michigan states are selected as an example of the Muslim communities in the US. These states have a number of common demographic characteristics. Both have diverse communities including Muslim, African American, and Hispanic (Table-2). Muslims live more in specific cities such as Detroit and Paterson within these states. The following information exposing the similarities between these states is the main reason for the comparison of media outlets of these states.

Michigan, Detroit is a well known place with its Arab origin Muslim population. Detroit, especially Dearborn part of the city, attracted more Arab immigrants after 1965. It is claimed to have the largest number of Arab immigrants (Badry, 2001). "With a population of 70,000, they compose of approximately one-seventh of Detroit's population" (Badry, 2001). Directory of Religious Centers also demonstrates more than 100 mosques in the state. The population estimates of Muslims in all Michigan range from 200,000 to 300,000 (Mujahid, 2001; Numan 1990).

Similarly, New Jersey is one of the most religiously and ethnically diverse states in the US. "With an estimated 250,000 Arab-Americans and an additional non-Arab Muslim population of about 450,000 in New Jersey reside in the second largest Muslim population by percent after Michigan" (Daily Record News, 
Yüksel, Y., \& Akbulut, A. (2015). Representation of the cartoon controversy on the U.S. newspapers. International Journal of Human Sciences, 12(1), 487-510. doi: 10.14687/ijhs.v12i1.3074

December 27, 2002). Majority of the Muslim population in New Jersey reside in the Paterson city. Similar to Michigan, Directory of Religious Centers demonstrates nearly 100 mosques in the state.

(Daily Record News, December 27, 2002).

\section{Non-Muslim Communities in the US}

In contrast to these regions, the southeast and especially northwest parts of the US have the fewest Muslim immigrants (Kosmin \& Mayer, 2001; Mujahid, 2001). According to Directory of Religious Centers prepared by Harvard Pluralism Project, northwest states contain a range of 1 to 9 mosques. According to detailed figures on mosques, Wyoming had only 2 mosques and Nebraska had 4 mosques in 2001. These states also reside in non-diverse communities compared to New Jersey and Michigan (Table-3). Considering these demographics, a newspaper from each state is taken in to sample of this study. Selection of certain newspapers in these states is explained below.

\section{Methodology}

\section{Newspaper Sampling and Information about the Newspapers}

The comparison requires taking into account the demographics of the circulation area, location, and circulation rates of the newspapers.. With this in mind, four sampling criteria were determined including:

1- The Muslim population in the circulation area,

2- The circulation rates of the newspapers in the region

3- The number of stories covering cartoon controversy

4- The ideological position of the newspaper

The following table gives a comparison of the 4 media outlets selected for this study in terms of daily circulation, circulation area, and circulation position, diversity of circulation and newsroom staff of newspapers. Following this, the details of the comparison is discussed. 
Yüksel, Y., \& Akbulut, A. (2015). Representation of the cartoon controversy on the U.S. newspapers. International Journal of Human Sciences, 12(1), 487-510. doi: 10.14687/ijhs.v12i1.3074

Table 1: Comparison of the Newspapers

\begin{tabular}{|c|c|c|c|c|c|c|}
\hline & Circulation & $\begin{array}{l}\text { Circulation } \\
\text { Area }\end{array}$ & $\begin{array}{c}\text { Circulation } \\
\text { Position } \\
\end{array}$ & Location & $\begin{array}{c}\text { Non-white } \% \\
\text { of circulation } \\
\text { area }\end{array}$ & $\begin{array}{c}\text { Non-white } \% \\
\text { of newsroom } \\
\text { staff }\end{array}$ \\
\hline $\begin{array}{l}\text { Herald } \\
\text { News }\end{array}$ & $40,000-50,000$ & Passaic County & First in City & $\begin{array}{l}\text { New Jersey } \\
\text { Passaic West } \\
\text { Paterson }\end{array}$ & 48.5 & 22.1 \\
\hline $\begin{array}{c}\text { Detroit Free } \\
\text { Press }\end{array}$ & $\begin{array}{l}350,000- \\
400,000\end{array}$ & $\begin{array}{c}\text { Detroit and } \\
\text { Southeastern } \\
\text { Michigan }\end{array}$ & First in State & $\begin{array}{c}\text { Michigan } \\
\text { Wayne County } \\
\text { Detroit } \\
\end{array}$ & 28.1 & 29.2 \\
\hline $\begin{array}{l}\text { Wyoming } \\
\text { Tribune- } \\
\text { Eagle }\end{array}$ & $15,000-20,000$ & $\begin{array}{c}\text { Southeast } \\
\text { Wyoming and } \\
\text { Laramie } \\
\text { County }\end{array}$ & Second in State & $\begin{array}{l}\text { Wyoming } \\
\text { Laramie } \\
\text { County } \\
\text { Cheyenne }\end{array}$ & 16.8 & 6.3 \\
\hline $\begin{array}{c}\text { Omaha } \\
\text { World News }\end{array}$ & $\begin{array}{l}200,000- \\
250,000\end{array}$ & $\begin{array}{l}\text { Nebraska and } \\
\text { Western Iowa }\end{array}$ & First in State & $\begin{array}{l}\text { Nebraska } \\
\text { Douglas } \\
\text { County } \\
\text { Omaha }\end{array}$ & 12.1 & 6.5 \\
\hline
\end{tabular}

Source 1: Official web pages of the newspapers and media Group (Circulation and Location)*

Source 2: Audit Bureau of Circulation (Circulation and Circulation Rank)

Source 3: Newsroom Diversity Report (Race / Ethnicity) ${ }^{*}$

Muslim population in the circulation area is the main issue considered during the selection of the newspapers. As mentioned earlier, the diversity of the population in the circulation area of the Herald News and Detroit Free Press presents a great extent of similarities. The circulation areas of these two newspapers include much more Muslim population than the other two newspapers. Although the race and ethnicity was not a main criterion considered in the study, the high non-white percentage of the population in the circulation area of Herald News and Detroit Free Press was another common aspect of both regions (Table-2).

Northwest of the US has less Muslim population than the other regions. For this reason, two newspapers from the northwest (Omaha and Wyoming) are taken in to the sample of the study. Omaha World-News and Wyoming Tribune-Eagle are selected as the sample of the newspapers in these

\footnotetext{
* Total Circulation is given approximately because of the difference between Audit Bureau of Circulation and Official web pages.

* This report is conducted by Bell Dedman and Stephen K. Doig in June 1, 2005. This report prepared by Knight Foundation shows trends at 1,410 US newspapers. For detailed information: http://powerreporting.com/knight/
} 
Yüksel, Y., \& Akbulut, A. (2015). Representation of the cartoon controversy on the U.S. newspapers. International Journal of Human Sciences, 12(1), 487-510. doi: 10.14687/ijhs.v12i1.3074

regions. Not only the population of the Muslims, but also the population of other race and ethnicities in these states were less than Michigan (Detroit) and New Jersey (Paterson) (Table-2, 3). Following tables shows the diversity and population of the circulation area of four newspapers. However, because of the reasons stated earlier, the tables do not include the percentage of the Muslims in these regions.

Table-2 Race/Ethnicity in the circulation area of Detroit Free Press and Herald News

\begin{tabular}{|l|c|c|c|c|}
\hline \multicolumn{2}{|l|}{ Detroit Free Press } \\
\multicolumn{3}{|l|}{ Herald News } \\
\hline Race/ethnicity & \% of population & \%umber of residents & \% of population & Number of residents \\
\hline & & & & 146,492 \\
\hline Hispanic & 2.6 & 94,422 & 30.0 & 60,528 \\
\hline Black and Pacific & 22.7 & 829,961 & 12.4 & 17,841 \\
\hline $\begin{array}{l}\text { Asian and } \\
\text { Islander }\end{array}$ & 2.6 & 96,053 & 3.7 & 802 \\
\hline Native-American & 0.3 & 11,970 & 0.2 & 1,185 \\
\hline Other non-white & 0.1 & 4,956 & 0.2 & 10,514 \\
\hline Multi-racial & 1.9 & 70,751 & 2.2 & 237,362 \\
\hline Non-white & 30.3 & $1,108,113$ & 48.5 & 251,687 \\
\hline White & 69.7 & $2,549,101$ & 51.5 & 489,049 \\
\hline Total & & $3,657,214$ & & \\
\hline
\end{tabular}

Source: Newsroom Diversity Report (Race / Ethnicity), 2005, http://powerreporting.com/knight/

Table-3 Race/Ethnicity in the circulation area of Omaha World-News and Wyoming Tribune

\begin{tabular}{|c|c|c|c|c|}
\hline \multirow[b]{2}{*}{ Race/ethnicity } & \multicolumn{2}{|c|}{ Omaha World-Herald } & \multicolumn{2}{|c|}{ Wyoming Tribune Eagle } \\
\hline & $\%$ of population & Number of residents & $\%$ of population & Number of residents \\
\hline Hispanic & 5.0 & 69,508 & 10.9 & 8,912 \\
\hline Black & 4.5 & 61,697 & 2.5 & 2,015 \\
\hline Asian and Pacific & 1.0 & 14,384 & 1.0 & 814 \\
\hline Native-American & 0.6 & 7,594 & 0.7 & 554 \\
\hline Other non-white & 0.1 & 966 & 0.1 & 97 \\
\hline Multi-racial & 1.0 & 13,516 & 1.6 & 1,325 \\
\hline Non-white & 12.1 & 167,665 & 16.8 & 13,717 \\
\hline White & 87.9 & $1,214,925$ & 83.2 & 68,128 \\
\hline Total & & $1,382,590$ & & 81,845 \\
\hline
\end{tabular}

Source: Newsroom Diversity Report (Race / Ethnicity), 2005, http:/ / powerreporting.com/knight/

Second sampling criterion is the circulation rates of the newspapers. After determining the location, the largest newspapers in that specific region are selected for the study. The logic behind this criterion is that the more they sell, the more they represent the region. As it is shown in Table-1, Omaha World-News and Detroit Free Press are the largest newspapers in the state. Herald News is the largest in Paterson, Muslim diverse part of the New Jersey. Wyoming Tribune-Eagle is the secondlargest daily newspaper in the state. 
Yüksel, Y., \& Akbulut, A. (2015). Representation of the cartoon controversy on the U.S. newspapers. International Journal of Human Sciences, 12(1), 487-510. doi: 10.14687/ijhs.v12i1.3074

The selection of the second largest newspaper in this state deals with the third criterion which is the number of stories covering cartoon controversy. The largest newspaper in Wyoming, Casper Star Tribune, included less and insufficient number of stories compared to the Wyoming Tribune-Eagle. The fact that Wyoming Tribune-Eagle republished the cartoons which is another reason leading the selection of the second-largest newspaper in this state. The other three newspapers provided enough stories for an evaluation.

The selection of the largest newspapers in the region correlated with the expectancy of being in the mainstream. Within this context, the newspapers are analyzed whether they have strict ideological background and distinctions. None of the newspapers surveyed in this study do not have strict ideological distinctions and marginal background but rather have tended to sit together on fairly central ground which verifies our expectancy in a way.

\section{Data Collection}

A content analysis of Detroit Free Press, Herald News, Omaba World-News and Wyoming Tribune-Eagle newspapers is performed to measure media attention and approach toward the cartoon controversy, namely publication of the cartoons and reaction of the Muslims to the publication of the cartoons. The coverage of these newspapers formed the empirical basis for this study.

The research on databases showed that most of the stories on this issue were published in February, 2006. That's why; the stories in February were evaluated. Keyword searches in the LexisNexis (some of the newspapers are not available in this database) database and World Access News database with the terms "Freedom", "Muhammad", "Prophet" and "Cartoon" provided the sample of stories about the case in the form of reports, articles and letters to editor. İrelevant stories generated by the search were removed.

\section{Data Analysis}

Content analysis is used to examine not only quantity but also the quality of stories in the newspapers. Within this context, the frequency of stories in the newspapers and the approach of these stories to the cartoon controversy are taken into account to provide the data for the research questions. In quantitative side, total number of reports, letters to editor and articles are analyzed. In qualitative side, the tone of the media coverage on these issues is analyzed. 
Yüksel, Y., \& Akbulut, A. (2015). Representation of the cartoon controversy on the U.S. newspapers. International Journal of Human Sciences, 12(1), 487-510. doi: 10.14687/ijhs.v12i1.3074

The tone of the coverage is the most important part of the study. The 'support the cartoons' category includes stories providing explicitly support the publication of the cartoons in the name of freedom of speech and press. Moreover, this category includes some stories supporting the idea that the cartoons are not example of hate speech because they are just satire. The 'oppose the cartoons' category includes those containing negative judgments about the publication of the cartoons. The stories in this category mainly focus on the meaning of freedom of speech and its limitations in the name of responsibility, tolerance, respect, and social harmony. The 'neutral or both' category includes those describing the issues in a balanced way, containing a mix of positive and negative judgments.

The second issue under this part is the reaction of the Muslims to the cartoon controversy. The 'support the reactions' category includes stories providing information about peaceful reactions of the Muslims and Muslims view which condemn the overreactions by the Muslims in other countries. The 'oppose the reactions' category includes those reporting only the protests which resulted in casualties and violence and criticizing the reaction of the Muslims on this issue. The 'neutral or both' category includes those reporting both peaceful and violent protest in a balanced way, containing a mix of positive and negative judgments.

The content analysis of the newspapers is based primarily on headlines, where these are adequate to provide the data for an evaluation. Headlines are important because "the impact of headlines on the reader is likely to be all the stronger because certain linguistic features of titles make them particularly memorable and effective" (as cited in Develotte \& Rechniewski, 1997: 1). First, that "it results from a 'replacement effect' (headlines stand in for the content of the article because few people read it fully) or, second, that it results from a 'framing effect' (beadlines frame the interpretation of the article content)" (Robertson, 2004: 464). Most of the headlines provided the data either on the reactions of the Muslims or the publication of the cartoons. In addition, "some reports had quite enigmatic headlines and required the extraction of further text so as to be certain about the thrust of the author's narrative" (Robertson, 2004: 464). Thus, most of the stories required deeper reading.

\section{Coding Procedure}

The coding judgments for this study are performed by three graduate students. The first coder is from Criminal Justice Program at Rutgers University, and the second coder is from Computer Sciences Program at CUNY. The third coder (the researcher) is from Communication Department at Rutgers University. 
Yüksel, Y., \& Akbulut, A. (2015). Representation of the cartoon controversy on the U.S. newspapers. International Journal of Human Sciences, 12(1), 487-510. doi: 10.14687/ijhs.v12i1.3074

All the coders are informed about the content of the study. Each story is used as a unit. The researchers are provided with two coding sheets both of which include three categories for each unit (story). The first one includes 'oppose the cartoons', 'support the cartoons' and 'both and neutral' categories. The second sheet includes 'oppose the reaction, 'support the reaction' and 'both and neutral' categories. The coders coded the stories for two coding sheets.

In the first coding sheet, the stories were coded as ' 1 ', if they 'support the cartoons'. The stories were coded as ' 2 ', if they 'oppose the cartoons'. The stories were coded as ' 3 ' if they belong to the 'both and neutral' category. The same system is applied in the second coding sheet. Some examples of the headlines which are coded in different categories are given in the findings section. This may be helpful to see the distinction between the categories.

\section{Coder Reliability}

A study of this kind (religion issue) has a potential problem regarding the differences of cultural and religious background. When individuals read stories on certain issues, especially religion, they may interpret the stories differently depending on their background. The researcher warned the coders to consider the text context rather than culture-biased beliefs and evaluations. If one of the coders had been in another religion rather than Muslim, this limitation could have been tested. However, both coders were Muslim.

After the completion of the coding, the correlations between the evaluations of the first coders and the second coder was computed. The coders achieved an overall level of agreement of $84 \%$ on their decisions. An $80 \%$ agreement rate on decisions is seen sufficient to justify the reliability of the findings (Robertson, 2004).

\section{Limitations}

This study is limited with four newspapers' reports, letters to editor, and articles that only cover incidents about cartoon controversy in February. Main purpose of this study is the comparison of the newspapers published in Muslim or Non-Muslim communities. However, this study does not attempt to cover all the newspapers published in a sample region. There are many more newspapers published in these regions. Only one newspaper is selected from each region for comparison. Thus, these newspapers do not represent all the media outlets in the state or city. This is a significant limitation to consider. In other words, the findings would be different in other Muslim or Non-Muslim states or cities, even in the same city, if we had chosen another newspaper. 
Yüksel, Y., \& Akbulut, A. (2015). Representation of the cartoon controversy on the U.S. newspapers. International Journal of Human Sciences, 12(1), 487-510. doi: 10.14687/ijhs.v12i1.3074

This study can give an idea about the approach of the US news media in Muslim and Non-Muslim communities.

There was also limited number of stories, especially in the northeast newspapers. However, all the newspapers in this region which are eligible for the study published more or less similar number of stories. Thus, the number of the stories is another limitation of the study. As the sample size is not much, all the figures and their percentages must be interpreted carefully.

\section{Results}

\section{Number of Stories on Cartoon Controversy}

Table-4 shows the frequency of the stories published in the newspapers in February, 2006. This one offers a purely quantitative comparison of the weight given by each newspaper to the cartoon controversy. In reading the figures, the difference between Herald News/Detroit Free Press and Omaba World-Herald/Wyoming Tribune-Eagle has to be taken into account.

Table-4 Number of Coverage in February

\begin{tabular}{|c|c|c|c|c|}
\hline & Herald News & $\begin{array}{c}\text { Detroit Free } \\
\text { Press }\end{array}$ & $\begin{array}{c}\text { Omaha World- } \\
\text { Herald }\end{array}$ & $\begin{array}{c}\text { Wyoming } \\
\text { Tribune-Eagle }\end{array}$ \\
\hline Total of stories & 12 & 15 & 6 & 8 \\
(Frequency) & & & & \\
\hline
\end{tabular}

Immediately apparent in Table-4 is a tendency in Herald News and Detroit Free Press to allocate space more frequently to the stories of the cartoon controversy. In other words, Table-4 shows that Omaha World-Herald and Wyoming Tribune-Eagle attached less media attention to this case than the other two newspapers. In fact, this situation is valid for the other newspapers in the northwest region as well. Before the selection of above mentioned northwest newspapers, some other newspapers in the northwest region such as Lincoln Journal Star in Nebraska, Argus Leader in South Dakota were examined to determine whether they generate more stories on the carton controversy. However, the number of stories in these newspapers was more or less in the same amount which offers the evidence of less media attention of the newspapers in the northwest. Interestingly, although Wyoming Tribune-Eagle republished the cartoons in this process, there were only 8 stories on this issue. The number of stories in Herald News and Detroit Free Press was relatively more than the Wyoming Tribune-Eagle and Omaha World-News. The more the 
Yüksel, Y., \& Akbulut, A. (2015). Representation of the cartoon controversy on the U.S. newspapers. International Journal of Human Sciences, 12(1), 487-510. doi: 10.14687/ijhs.v12i1.3074

newspapers have Muslims in their circulation area, the more stories about the topics related to Muslims may be expected to be published. This demonstrates the correlation between the target population and media attention. There may be so many other variables affecting the number of stories on a certain race/ethnicity including the ideology of the newspaper, its page numbers, its being tabloid or serious, its attention to international issues, and the ownership of the newspaper. Although the application of some selection criteria for the newspapers in order to find a newspaper representing to the region in which they are published, it is hard to control all above mentioned variables. However, by looking at simply the number of stories in the northwest newspapers, it is reasonable to tell that there is a correlation between media attention and target population.

Table-5 The number of reports, articles and letters to editor in each newspaper in February

\begin{tabular}{|c|c|c|c|c|}
\hline & Herald News & $\begin{array}{c}\text { Detroit Free } \\
\text { Press }\end{array}$ & $\begin{array}{c}\text { Omaha World- } \\
\text { Herald }\end{array}$ & $\begin{array}{c}\text { Wyoming } \\
\text { Tribune-Eagle }\end{array}$ \\
\hline Reports & $3(25 \%)$ & $3(20 \%)$ & $1(22 \%)$ & $2(25 \%)$ \\
\hline Articles & $4(33 \%)$ & $4(27 \%)$ & $2(33 \%)$ & $2(25 \%)$ \\
\hline Letters to Editor & $5(42 \%)$ & $8(53 \%)$ & $3(50 \%)$ & $4(50 \%)$ \\
\hline
\end{tabular}

Table- 5 shows the distribution of stories in the newspapers in February, 2006. There is not considerable difference among the newspapers regarding the percentage of reports, articles and letters to editor. Both Herald News/Detroit Free Press and Wyoming Tribune-Eagle/Omaha World-News have similar percentage rates for each unit. During the cartoon debate, all gave more space to readers in the form of letters to editor compared to articles and reports. Although Wyoming Tribune-Eagle and Omaha World-News have mostly Non-Muslim communities, they also gave space to Muslims and other community members in these letters.

\section{Approach of the Newspapers to Publish Cartoons}

The main interest of the study is the approach of the newspapers to the cartoon controversy and difference among them. Table- 6 and Table- 7 demonstrate the approach of the newspapers on two different things including the publication of the cartoons and reaction of the Muslims to these cartoons. Some of the stories focus on both issues, some of them not. Because the percentages are given by considering total number of stories $(\mathrm{N})$, the percentages must be interpreted carefully. 
Yüksel, Y., \& Akbulut, A. (2015). Representation of the cartoon controversy on the U.S. newspapers. International Journal of Human Sciences, 12(1), 487-510. doi: 10.14687/ijhs.v12i1.3074

Table-6 The number of stories supporting, opposing and both/neutral to publish of cartoons*

\begin{tabular}{|c|c|c|c|c|}
\hline & Herald News & $\begin{array}{c}\text { Detroit Free } \\
\text { Press }\end{array}$ & $\begin{array}{c}\text { Omaha World- } \\
\text { Herald }\end{array}$ & $\begin{array}{c}\text { Wyoming } \\
\text { Tribune-Eagle }\end{array}$ \\
$\mathbf{( N = 1 5 )}$ & $\mathbf{( N = 6 )}$ & $\mathbf{( N = 8 )}$ \\
\hline $\begin{array}{c}\text { Support the } \\
\text { Cartoons }\end{array}$ & $3(25 \%)$ & $2(13 \%)$ & $2(33 \%)$ & $3(38 \%)$ \\
\hline $\begin{array}{c}\text { Oppose the } \\
\text { Cartoons }\end{array}$ & $4(33 \%)$ & $8(53 \%)$ & $3(50 \%)$ & $4(50 \%)$ \\
\hline $\begin{array}{c}\text { Both/Neutral } \\
\text { Soth) }\end{array}$ & $2(16 \%)$ & $3(20 \%)$ & - & $1(12 \%)$ \\
\hline $\begin{array}{c}\text { Not } \\
\text { Mentioned }\end{array}$ & $3(25 \%)$ & $2(13 \%)$ & $1(16 \%)$ & $1(12 \%)$ \\
\hline
\end{tabular}

Immediately apparent in Table-6 is an overall tendency in the newspapers, especially in Detroit Free Press to oppose the publication of the cartoons. However, all four newspapers gave space to stories supporting the publication of the cartoons. Except for Wyoming Tribune-Eagle, the other three newspapers have declined to publish the cartoons like the major American newspapers. However, there were still 4 stories in Wyoming Tribune-Eagle opposing the publication of the cartoons most of which are reader letters. Wyoming Tribune-Eagle seems to balance the publication of the cartoons with the letters coming from the readers. These figures do not mean that these newspapers are against freedom of speech. They all supported freedom of speech in their stories, but the stories which oppose the publication of the cartoons focused on the importance of responsibility, understanding, and respect. They also gave space to Muslims living in the circulation area of the newspaper in their reports and letters to editor part. Table- 5 shows the number of letters to editor which clearly resulted in the increase in the 'oppose the cartoons' category. This is especially valid for Detroit Free Press and Herald News.

Table-6 does not suggest considerable difference between the two groups of newspapers with regard to the publication of the cartoons. All four newspapers presented a more negative view of the publication of the cartoons. However, the deeper reading of the stories shows another distinction between the two groups of newspapers. The views and activities of the Muslims, Muslim leaders, and organizations on cartoon controversy were presented much more in the Detroit Free Press /Herald News than Wyoming Tribune-Eagle/Omaha World-News. There were some reports, letters to editor, and articles in Wyoming Tribune-Eagle and Omaba World-News which provided space for the

\footnotetext{
* Percentages are determined considering total number of stories.
} 
Yüksel, Y., \& Akbulut, A. (2015). Representation of the cartoon controversy on the U.S. newspapers. International Journal of Human Sciences, 12(1), 487-510. doi: 10.14687/ijhs.v12i1.3074

Muslims in their circulation area. However, there is a considerable difference in the amount of the direct quotations between each group of newspapers on this issue.

\section{The Headlines of the Newspapers about the Publication of Cartoons}

The comparative presentation of some headlines in each newspaper may offer further and important evidence of how they performed during the cartoon controversy. Both newspapers had headlines conveying a range of perspective on the publication of the cartoons. Following ones clearly 'oppose' the publication of the cartoons in the headlines:

In the Herald News.

"Muhammad was ambassador of peace" (February 27)

"Cartoon seen as far from funny" (February 5)

In the Detroit Free Press:

"Find a way to better relations" (February 12)

“Toward greater sensitivity” (February 10)

"Muslim leaders urge restraint over offensive cartoons" (February 4)

In the Wyoming Tribune-Eagle, as the newspaper chose to publish the cartoons, there was a clear distinction in the headlines which support or oppose the publication of the cartoons. The ones which oppose are as follows:

"Publishing cartoons is really irresponsible" (February 22)

"Cartoon was too offensive to print" (February 22)

"Cartoons disturb local Muslims" (February 11)

In the Omaha World-News:

"U.S. advantages U.S. society can teach much to Europeans about building constructive relations with Muslims” (February 23) 

of Human Sciences, 12(1), 487-510. doi: 10.14687/ijhs.v12i1.3074

"Muslim group hopes to spread message of peace" (February 14)

The following headlines show the stories which clearly support the publication of the cartoons. There were less examples of this group of headlines in the newspapers. There was not any in the Omaha World News which had more headlines on the reaction of the Muslims:

In the Herald News.

"Publish the cartoons" (February 12)

The pen meets the sword; Freedom of speech in the West viewed as blasphemy in the Middle East (February 10)

In the Detroit Free Press:

"Free expression under attack" (February 10)

"Stand for freedom" (February 10)

In the Wyoming Tribune-Eagle:

“True example of America's free press" (February 12)

"WTE is right to print Muhammad cartoons" (February 10)

"Cartoons challenge readers to think about their world; "I may disapprove of what you say, but will defend to the death your right to say it".’(February, 8)

The stories which oppose the publication of the cartoons focused on peace, respect, understanding, and responsibility. The stories which support the publication of the cartoons put more emphasize on the freedom of press and expression and the meaning and importance of it for the American public. Moreover, the stories in this group focus on the contribution of free press to develop clearer and stronger ideas.

\section{Approach of Newspapers to the Reaction of the Muslims}

In contrast to the publication of the cartoons, as the violent protests developed all around the world, all four newspapers gave considerable coverage to critical reader letters, articles and reports 
Yüksel, Y., \& Akbulut, A. (2015). Representation of the cartoon controversy on the U.S. newspapers. International Journal of Human Sciences, 12(1), 487-510. doi: 10.14687/ijhs.v12i1.3074

on the violent reaction of the Muslims, especially in the Middle East countries. The following table shows the number of stories and approach of each newspapers on this issue.

Table-7 The number of stories supporting, opposing, both/neutral to reaction of Muslims *

\begin{tabular}{|c|c|c|c|c|}
\hline & Herald News & $\begin{array}{c}\text { Detroit Free } \\
\text { Press }\end{array}$ & $\begin{array}{c}\text { Omaha World- } \\
\text { Herald }\end{array}$ & $\begin{array}{c}\text { Wyoming } \\
\text { Tribune-Eagle }\end{array}$ \\
\hline $\begin{array}{c}\text { Support the } \\
\text { Reaction }\end{array}$ & $1(8 \%)$ & - & - & (N=6) \\
\hline $\begin{array}{c}\text { Oppose the } \\
\text { Reaction }\end{array}$ & $4(33 \%)$ & $7(47 \%)$ & $4(67 \%)$ & $2(25 \%)$ \\
\hline $\begin{array}{c}\text { Both/Neutral } \\
\text { (N=12) }\end{array}$ & $3(25 \%)$ & $2(13 \%)$ & - & $1(12 \%)$ \\
\hline $\begin{array}{c}\text { Not } \\
\text { Mentioned }\end{array}$ & $4(33 \%)$ & $6(40 \%)$ & $2(33 \%)$ & $5(63 \%)$ \\
\hline
\end{tabular}

In contrast to the Omaba World-News, the Wyoming Tribune-Eagle put more emphasize on the freedom of speech debate rather than the reactions. There were only 3 stories out of 8 in Wyoming Tribune-Eagle which connected with the reaction of the Muslims. As a result, the low percentage of stories which oppose the reaction of the Muslims must be interpreted carefully. In fact, 2 out of 3 stories opposed the reaction of the Muslims which indicates $66 \%$ of 3 stories. The reason of tendency to the publication of the cartoons rather than the reactions was the publication of the cartoon in this newspaper. By contrast, Omaha World-News mostly reflected protests which resulted in casualties and violence.

There were relatively more stories in Herald News/Detroit Free Press opposing the violent reactions of the Muslims. However, Herald News/Detroit Free Press was more likely to balance these stories by other stories covering peaceful protests or the speech of American Muslims against the violence in other countries. This representation is correlated with the general understanding of American public about relationship between Islam and violence. "More than one-in-three Americans, for instance, say that Islam is more likely than other religions to encourage violence among its believers" (Pew Research Center, 2006).

As a result, it can be concluded that there is not a considerable but slight difference in each group of newspapers regarding the representation of the reactions of the Muslims. All four newspapers

\footnotetext{
* Percentages are determined considering total number of stories.
} 

of Human Sciences, 12(1), 487-510. doi: 10.14687/ijhs.v12i1.3074

presented a negative view of the reaction of the Muslims. However, Wyoming Tribune-Eagle/Omaba World-News presented a more negative view of the reaction of the Muslims than Herald News/Detroit Free Press. Herald News and Detroit Free Press covered the reaction of the Muslim community in their circulation area more than the Omaba World-News and Wyoming Tribune-Eagle. Most of these stories covered the peaceful protest of the local Muslim groups or their critiques about the reaction of the Muslims living overseas.

To sum up, although all newspapers clearly presented a negative view of the reactions of the Muslims, Herald News/Detroit Free Press balanced this negativity by stories which covered either the peaceful protest of the local Muslim groups or the critiques of local Muslims and organizations for the overreaction overseas.

\section{The Headlines of the Newspapers about the Reaction of the Muslims}

The comparative presentation of some key headlines in each newspaper may offer further and important evidence of how they presented the reaction. As it is understood from the headlines, the followings demonstrate 'oppose the reaction' category:

In the Herald News:

"Islamic cartoon protests go too far" (February 24)

"Violence silences debate" (February, 12)

In the Detroit Free Press:

“Religious groups decry reaction to caricatures’ (February 8)

In the Omaha World-News:

"What would these people do if they had nuclear weapons?" (February 13)

The headlines under the category of 'support the reaction' and 'both/neutral' are as follows: There is not any headline in Omaha World-News and Wyoming Tribune-Eagle in this category.

In the Herald News:

"Faithful protest" (February 20) 
Yüksel, Y., \& Akbulut, A. (2015). Representation of the cartoon controversy on the U.S. newspapers. International Journal of Human Sciences, 12(1), 487-510. doi: 10.14687/ijhs.v12i1.3074

"Youthful face of protest" (February 19)

In the Detroit Free Press:

"Muslims protest overreact to cartoons of Muhammad" (February 10)

"Hundreds attend rally; Muslims gather at Danish Mission to protest cartoons" (February 18)

The stories which oppose the reaction of the Muslims focused on overreaction, the way of reaction, the number of casualties, and violent protest in other countries. The stories which support the reaction of the Muslims put more emphasize on the peaceful protest of local Muslim communities, the statements of local Muslims and Muslim organizations which condemn the violent reaction of the Muslims in the other countries.

\section{Conclusion}

The general approach of the US newspapers to the cartoon controversy was different from the European newspapers which chose to republish the cartoons in the name of freedom of speech and press. Nearly all newspapers have chosen not to publish these cartoons in the US, with a few exceptions. Similarly, the politicians mostly followed different direction than European colleagues. Within this mind, it was interesting to analyze the attention and approach of the news media to the cartoon controversy in different parts of the US. The more interesting thing to analyze was whether there was a difference between newspapers depending on Muslim population in their circulation area.

If we look at the media attention to this case, the overall results of content analysis show that the newspapers published in Muslim diverse communities are likely to draw more attention to the cartoon controversy. During the carton controversy, all four newspapers gave space to a wide range of opinion. As mentioned earlier, they gave generous space to a wide range of very high quality comment from readers. In reporting the case, all four newspapers covered the stories which 'oppose the cartoons' and 'support the cartoons'. By contrast, the reaction of the Muslims was covered a little differently in each group of newspapers. Detroit Free Press/Herald News covered the categories including 'oppose the reaction', 'support the reaction' and 'both/neutral', where as Wyoming Tribune-Eagle/Omaha World News covered only 'oppose the reaction' category with an exception. 
Yüksel, Y., \& Akbulut, A. (2015). Representation of the cartoon controversy on the U.S. newspapers. International Journal of Human Sciences, 12(1), 487-510. doi: 10.14687/ijhs.v12i1.3074

Consequently, this study did not support the first hypothesis. Neither Detroit Free Press/Herald News nor Wyoming Tribune-Eagle/Omaha World-News supported the publication of the cartoons. Although there were some differences in quality and the quantity of stories, these were not considerable. This study did not support the second hypothesis, too. All four newspapers covered more stories which oppose the reaction of the Muslims to the cartoons. However, there was a difference between each group to take in to account. The newspapers in Muslim communities not only covered the stories including violent protest and casualties but also covered peaceful protest, especially in the local area and Muslim's views as to overreaction of Muslims in other countries.

In fact, the crisis could have been stopped almost immediately from getting worse; however, it turned into an international crisis due to wrong policies. By missing or ignoring opportunities to control the controversy at an early stage, the editors of Jyllands-Posten, Muslim leaders and Danish politicians all contributed to this dispute. The real fact that Europe and the world at large face to a potentially dangerous situation. The Danish nationalistic party has already gained many new members. This is an instigation to ruin social peace in Europe and the efforts for inter-religious dialogue among world leaders. This case has just inflamed the mutual distrust between the West and the Islamic world; among the European societies and Muslim groups in these societies.

In this specific case, the methods to use do not have to be necessarily legal restrictions. It should have been in the limits of social responsibility in favor of public order. Politicians should at least declare not to use this right in the name responsibility. There is certainly a freedom of expression and speech, but if you do not take others' thoughts into consideration you will leave them with no freedom. A pluralistic society can maintain its cohesion only if its members exercise their freedom with attention to the sensitivities of others. Globalization has made ours a multicultural world. Fostering peace among cultures will depend on adopting ourselves to the values and feelings.

Muslims should take more responsibility in this kind of cases. Islam is not known around the world. Islam respects all the Prophets and Muslims expect the same from the followers of other religions and ideologies. Unfortunately, Islam reminds some terrorists to European people. As a result, it is time for all Muslims and Islam countries to follow an active program with solidarity and cooperation in order to eradicate the prejudices. Muslims should consider how to use media for positive portrayal of Islam. At least, Muslims consider using the internet actively to express themselves as an alternative to the television and newspapers. Westerners should become more aware of what angers Muslims, and thus less provocative; Muslims should become more aware that 
Yüksel, Y., \& Akbulut, A. (2015). Representation of the cartoon controversy on the U.S. newspapers. International Journal of Human Sciences, 12(1), 487-510. doi: 10.14687/ijhs.v12i1.3074

freedom of speech is a praiseworthy Western tradition, not a weapon against Islam. However, that is and should be their own decision, not a decision by governments.

\section{References}

Badry, S. (2001). Arab American Demographics. Retrieved October 10, 2014, from http://www.allied-media.com/Arab-American/Arab\%20american\%20Demographics.htm

Beinart, P. (February 6, 2006). Religious Experience. The new republic. Retrieved October 10, 2014, from Ebscohost Database.

Brems, E. (2002). State regulation of xenophobia versus individual freedoms: the European view. Journal of Human Rights, 1 (4). 481-500.

Brinkley, J. \& Fisher, I. (February 04, 2006). U.S. says it also finds cartoons of Muhammad offensive. $\quad$ Retrieved $\quad$ October $10, \quad 2014, \quad$ from http://www.nytimes.com/2006/02/04/politics/04mideast.html?pagewanted $=$ all \& $r=0$

Cowan, G. \& Khatchadourian, D. (2003). Empathy, ways of knowing, and interdependence as mediators of gender differences in attitudes toward hate speech and freedom of speech. Psychology of Women Quarterly, 27, 300-308.

Dedman, B. \& Doig S. K. (2005). Report for the Knight Foundation shows trends at 1,410 US newspapers. Retrieved October 10, 2014, from http://powerreporting.com/knight/

Fattah, H. M. (February 09, 2006). The Protests: At Mecca Meeting, Cartoon Outrage Crystallized. Retrieved Retrieved October 10, 2014, from http://www.nytimes.com/2006/02/09/international/middleeast/09cartoon.html?pagewan ted $=$ all

Huda, Q. (February, 2006). United States Institute of Peace Special Report. Retrieved June 10, 2010, from http://www.usip.org/pubs/specialreports/sr159.pdf

Ikuenobe, P. (2003). Optimizing Reasonableness, Critical Thinking, and Cyberspace. Educational Philosophy and Theory. 35 (4), 408-424.

Khan, S. (February 08, 2006). Cartoons show disregard for sacred Muslim beliefs. Retrieved October 10, 2014, from http://usatoday30.usatoday.com/news/opinion/editorials/200602-07-letters-cartoons x.htm

Kosmin, B.A. \& Mayer, E. (2001) American religious Identification Survey. Retrieved October 10, 2014, from http://www.gc.cuny.edu/CUNY GC/media/CUNY-GraduateCenter/PDF/ARIS/ARIS-PDF-version.pdf

Ladenson, R. F. (1997). Is the Right of Free Speech Special? Social Theory and Practice, 23 (2), 350368.

Martinson, D.L. (2005). Building a Tolerance for Disagreement an Important Goal in Social Studies Instruction. College Media review, 78 (3), 118-124.

Mill, J.S. (1978) On Liberty, Hackett Publishing:Indianapolis.

Numan, F. H. (1990). The Muslim population in the United States: Brief Statement, American Muslim Council. Retrieved October 10, 2014, from Ebscohost Database.

Smith, J. (2006). Patterns of Muslim immigration. Retrieved October 10, 2014, from http://www.4uth.gov.ua/usa/english/society/muslimlife/immigrat.htm 

of Human Sciences, 12(1), 487-510. doi: 10.14687/ijhs.v12i1.3074

Staphone, P. D. (February 08, 2006). Faith, free speech: Where to draw the line? Retrieved March 27, 2006, from http://www.usatoday.com

Robertson, J. W. (2004). People's Watchdogs or Government Poodles ? European Journal of Communication, 19 (4), 457-482.

Reynolds, P. (February 09, 2006). Cartoons: Divisions and inconsistencies. Retrieved October 10, 2014, from http://news.bbc.co.uk/2/hi/asia-pacific/4708216.stm

United Nations (1948). Universal Declaration of Human Rights, Retrieved on May 20, 2014 from http://www.un.org/en/documents/udhr/ 